\title{
Antioxidant and angiotensin I-converting enzyme inhibitory activities of northern shrimp (Pandalus borealis) by-products hydrolysate by enzymatic hydrolysis
}

\author{
Sang-Bo Kim, Na Young Yoon, Kil-Bo Shim and Chi-Won Lim*
}

\begin{abstract}
In the present study, we investigated to the antioxidant and angiotensin I-converting enzyme (ACE) inhibitory activities of the northern shrimp (Pandalus borealis) by-products (PBB) hydrolysates prepared by enzymatic hydrolysis. The antioxidant and ACE inhibitory activities of five enzymatic hydrolysates (alcalase, protamex, flavourzyme, papain, and trypsin) of PBB were evaluated by the 2, 2'-azino-bis [3-ethylbenzothiazoline-6-sulfonic acid] $\left(\mathrm{ABTS}^{+}\right.$) radical scavenging and superoxide dismutase (SOD)-like activities, reducing power and Li's method for ACE inhibitory activity. Of these PBB hydrolysates, the protamex hydrolysate exhibited the most potent ACE inhibitory activity with $\mathrm{IC}_{50}$ value of $0.08 \pm 0.00 \mathrm{mg} / \mathrm{mL}$. The PBB protamex hydrolysate was fractionated by two ultrafiltration membranes with 3 and $10 \mathrm{kDa}$ (below $3 \mathrm{kDa}$, between 3 and $10 \mathrm{kDa}$, and above $10 \mathrm{kDa}$ ). These three fractions were evaluated for the total amino acids composition, antioxidant, and ACE inhibitory activities. Among these fractions, the $<3 \mathrm{kDa}$ and 3-10 kDa fractions showed more potent $\mathrm{ABTS}^{+}$radical scavenging activity than that of $>10 \mathrm{kDa}$ fraction, while the $>10 \mathrm{kDa}$ fraction exhibited the significant reducing power than others. In addition, 3-10 kDa and $>10 \mathrm{kDa}$ fractions showed the significant ACE inhibitory activity. These results suggested that the high molecular weight enzymatic hydrolysate derived from PBB could be used for control oxidative stress and prevent hypertension.
\end{abstract}

Keywords: Northern shrimp, Enzymatic hydrolysate, Antioxidant, Angiotensin l-converting enzyme

Abbreviations: ACE, Angiotensin I converting enzyme; PBB, Pandalus borealis by-products; $\mathrm{ABTS}^{+}, 2,2^{\prime}$-Azinobis[3-ethylbenzothiazoline-6-sulfonic acid]; SOD, Superoxide dismutase; RAS, Renin angiotensin system; OPA, o-phthaldialdehyde; DMSO, Dimethyl sulfoxide; EDTA, Ethylenediaminetetraacetic acid; $\mathrm{K}_{3} \mathrm{Fe}(\mathrm{CN})_{6}$, Potassium ferricyanide; TCA, Trichloroacetic acid; HHL, Hippuryl-L-histidyl-L-leucine; BSC, Benzene sulfonyl chloride; $\mathrm{FeCl}_{3}$, Iron (III) chloride; MWCO, Molecular weight cut-offs; ROS, Reactive oxygen species

\section{Background}

Hypertension is one of the primary causes of cardiovascular disease which leads to stroke, coronary artery disease, and sudden cardiac death (Bhuyan and Mugesh 2011). The renin-angiotensin system (RAS) plays a key role in regulating blood volume and hypertension (Hall 1991; Hall et al. 1989). Angiotensin I-converting enzyme (ACE) is important in the functioning of the RAS. Renin converts angiotensinogen to angiotensin I, and ACE catalyzes cleavage of angiotensin I into angiotensin II which is the

* Correspondence: whasoo@korea.kr

Food Safety and Processing Research Division, National Institute of Fisheries Science, Busan 46083, South Korea main active component of hypertension (Paul et al. 2006; Takahashi et al. 2011). The increased angiotensin II causes vasoconstriction along with increased blood volume and water retention (Parish and Miller 1992). Several ACE inhibitors have been tested and developed in order to inhibit angiotensin II-mediated hypertension. Most synthetic ACE inhibitors such as captopril, enalapril, lisinopril, ramipril, and benzapril on the market have been reported with their side effects including skin rash, loss of taste, and dry cough (Dr and Lisa 2012). Moreover, a recent research has found that oxidative stress is a principal factor for hypertension (Bagatini et al. 2011). Excess reactive oxygen species affects cellular functions and reduces the 
bioavailability of endothelial nitric oxide and enhances low-density lipoprotein oxidation in the vascular system (Ray et al. 2012; Toeroek 2008; Mattson 2009). Therefore, there is a necessity for the development of new ACE inhibitors with potent oxidative stress inhibition and fewer side effects from natural resources.

Northern shrimp (Pandalus borealis), one of the most popular shrimp species in Korea, belongs to family Pandalidae and distributes widely in the deep sea at depths of 20-1330 $\mathrm{m}$ with a temperature of $2-14{ }^{\circ} \mathrm{C}$ found in the water around the eastern coast of Korea (Bauer 2004). This is rich in nutrients such as proteins, minerals, and vitamins. However, the inedible parts of shrimp by-products including head, shell, and tail portions account for approximately $50 \%$ of the catch and constitute valuable and useful bioactive materials, such as carotenoprotein, pigments, chitin, and chitosan (Chakrabarti 2002; Babu et al. 2008; Younes et al. 2015). Recently, much research has been carried out on the utilization of proteinrich fisheries by-products as nutraceuticals and nutritional supplements with high nutrient (Chae et al. 1998; Guerard et al. 2001; Arvanitoyannis and Kassaveti 2008).

The aim of the present study was to determine antioxidant and ACE inhibitory activities of enzymatic hydrolysates and its molecular weight cut-off fractions of the $P$. borealis by-products for prevention of hypertension.

\section{Methods}

\section{Materials}

$P$. borealis was purchased from the market of Yang yang-gun, Gangwon-do, Korea, in May, 2012. Alcalase $2.4 \mathrm{~L}$, papain, trypsin, serine, $o$-phthaldialdehyde (OPA), pyrogallol, 2, 2'-azino-bis [3-ethylbenzothiazoline-6-sulfonic acid] $\left(\mathrm{ABTS}^{+}\right)$, dimethyl sulfoxide (DMSO), ethylenediaminetetraacetic acid (EDTA), potassium ferricyanide $\left(\mathrm{K}_{3} \mathrm{Fe}(\mathrm{CN})_{6}\right)$, trichloroacetic acid (TCA), hippuryl-L-histidyl-L-leucine (HHL), angiotensin I-converting enzyme (ACE), sodium borate, sodium chloride, hydrochloric acid, pyridine, benzene sulfonyl chloride (BSC), captopril, and L-ascorbic acid were purchased from Sigma-Aldrich Chemical Co. (St. Louis, MO, USA) and iron(III) chloride $\left(\mathrm{FeCl}_{3}\right)$ was obtained from Junsei Chemical Co. (Tokyo, Japan). Protamex and flavourzyme were purchased from Novo Co. (Novozyme Laboratories, Copenhagen, Denmark).

Enzymatic hydrolysis and fractionation of shrimp by-product The by-products of $P$. borealis (PBB) were lyophilized and stored at $-20{ }^{\circ} \mathrm{C}$ until use. The crude protein content of PBB was $44.50 \pm 0.35 \%$ by AOAC method (AOAC, 2000) and enzymatic hydrolysis of $\mathrm{PBB}$ was performed using five enzymes, alcalase, papain, trypsin, protamex, and flavourzyme, under their optimal conditions (Table 1). A 100-g sample (on the basis of protein weight) and $1 \%$ enzyme were mixed and then the mixture was incubated for $8 \mathrm{~h}$ at
Table 1 The proximate compositions including moisture, crude fat, ash, and crude protein of PBB

\begin{tabular}{llllc}
\hline & Moisture (\%) & Crude fat (\%) & Ash (\%) & Crude protein (\%) \\
\hline PBB & $21.07 \pm 0.22$ & $12.19 \pm 0.12$ & $17.18 \pm 0.64$ & $44.50 \pm 0.35$ \\
Protamex & $7.05 \pm 0.21$ & $1.12 \pm 0.15$ & $18.35 \pm 0.21$ & $73.92 \pm 0.95$ \\
$<3 \mathrm{~K}$ & $14.04 \pm 0.13$ & $4.66 \pm 0.21$ & $15.85 \pm 0.18$ & $62.07 \pm 3.23$ \\
$3-10 \mathrm{~K}$ & $7.26 \pm 0.17$ & $2.27 \pm 0.25$ & $11.75 \pm 0.26$ & $69.31 \pm 2.11$ \\
$>10 \mathrm{~K}$ & $5.48 \pm 0.22$ & $2.30 \pm 0.17$ & $12.69 \pm 0.31$ & $74.02 \pm 2.63$ \\
\hline
\end{tabular}

The proximate composition of PBB was measured by AOAC methods

each optimal temperature with stirring. After incubation, the mixture was heated at $100{ }^{\circ} \mathrm{C}$ to inactivate the enzyme. The inactivated mixture was centrifuged at $2000 \times g$ for $20 \mathrm{~min}$. After centrifugation, the supernatant was lyophilized and stored at $-20{ }^{\circ} \mathrm{C}$ until use.

The protamex hydrolysate (38 g) was dissolved in $50 \mathrm{~mL}$ deionized water and filtered by two ultrafiltration membranes (Amicon Ultra-filter devices; Millipore, Billerica, MA, USA) with 3 and $10 \mathrm{kDa}$ molecular weight cut-offs $(<3 \mathrm{kDa}, 3-10 \mathrm{kDa}$, and $>10 \mathrm{kDa})$. The soluble fractions were prepared by centrifuging at $3000 \times g$ for $20 \mathrm{~min}$ and passed through the membrane sequentially, beginning with the largest molecular weight cut-off membrane cartridge $(10 \mathrm{kDa})$. The retentate and permeate were collected separately, and the retentate was recirculated into the feed until the maximum permeate yield was reached. Permeate from the $10 \mathrm{kDa}$ membrane was then filtered through the $3 \mathrm{kDa}$ membrane with recirculation until the maximum permeate yield was reached.

\section{Degree of hydrolysis (DH)}

The DH of enzymatic hydrolysates of PBB was calculated by determining free amino groups with OPA (Nielsen 2001).

$$
\mathrm{DH}=h / h_{\mathrm{tot}} \times 100
$$

where $h_{\text {tot }}$ is the total number of peptide bonds per protein equivalent, and $h$ is the number of hydrolyzed bonds. The factor $h_{\text {tot }}$ is dependent on the amino acids composition of the raw material (Adler-Nissen 1986).

\section{Total amino acids contents}

The total amino acids composition was determined using an amino acid analyzer (S43000; Sykam, Eresing, Germany). Samples were hydrolyzed in hydrochloric acid $(6 \mathrm{~N})$ in vacuum-sealed tubes at $110{ }^{\circ} \mathrm{C}$ for $24 \mathrm{~h}$.

Tryptophan is measured after alkaline hydrolysis (Sato et al. 1984). Samples (9-10 mg, $0.1 \mathrm{mg}$ precision) were dissolved in $10 \mathrm{~mL}$ of $4.2 \mathrm{~N}$ sodium hydroxide and hydrolysed in an oven at $110{ }^{\circ} \mathrm{C}$ for $20 \mathrm{~h}$. The hydrolysates were filtered using filter paper (ADVANTEC No. 5B) and mass up $50 \mathrm{~mL}$ by $0.2 \mathrm{~N}$ sodium citrate buffer $(\mathrm{pH}$ 
4.2). The $1-5 \mathrm{~mL}$ of solution was dried in a waterbath at $70{ }^{\circ} \mathrm{C}$. The $\mathrm{pH}$ of the hydrolysates was adjusted to 4.2 with $6 \mathrm{~N} \mathrm{HCl}$ and $0.2 \mathrm{~N}$ sodium citrate buffer and mass up $25 \mathrm{~mL}$. The solutions were filtered through $0.2 \mu \mathrm{m}$ membrane filter and analyzed by amino acid analyzer (Sykam 4300, Sykam, Germany).

\section{$\mathrm{ABTS}^{+}$radical scavenging activity}

The $\mathrm{ABTS}^{+}$radical scavenging activity was determined using the method of Roberta et al. (1999). The ABTS solution was diluted with water to achieve an absorbance of $0.75 \pm 0.03$ at $734 \mathrm{~nm}$. Then, $180 \mu \mathrm{L}$ of ABTS solution was added to $20 \mu \mathrm{L}$ of different concentrations of samples. The mixture was incubated in the dark for $10 \mathrm{~min}$ and measured the absorbance by spectrophotometer (BIO-TEK US/MQX 200, USA) at $734 \mathrm{~nm}$. L-ascorbic acid was used as a positive control and the $\mathrm{ABTS}^{+}$radical scavenging activity of each sample was expressed as $\mathrm{IC}_{50}$ value.

\section{Superoxide dismutase (SOD)-like activity}

The SOD-like activity of the sample was evaluated according to the procedure of Marklund and Marklund (1974) with a slight modification. One hundred microliters of sample solutions were mixed with $100 \mu \mathrm{L}$ of pyrogallol $(7.2 \mathrm{mM})$ and $100 \mu \mathrm{L}$ of $50 \mathrm{mM}$ Tris- $\mathrm{HCl}$ buffer at $\mathrm{pH} 8.5$ containing $0.2 \mathrm{mM}$ EDTA. After $10 \mathrm{~min}, 50 \mu \mathrm{L}$ of $1 \mathrm{~N} \mathrm{HCl}$ was added to the mixture to stop the reaction and measured the absorbance at $420 \mathrm{~nm}$. L-ascorbic acid was used as a positive control, and the SOD-like activity of the PBB was expressed as $\mathrm{IC}_{50}$ value.

\section{Reducing power}

The reducing power of shrimp shell extracts were measured by the method of Oyaizu (1986). Different concentrations of samples in $10 \%$ DMSO were mixed with $50 \mu \mathrm{L}$ of $0.2 \mathrm{M}$ sodium phosphate buffer ( $\mathrm{pH}$ 6.6) and $50 \mu \mathrm{L}$ of potassium ferricyanide $(10 \mathrm{mg} / \mathrm{mL})$. The mixtures were incubated at $50{ }^{\circ} \mathrm{C}$ for $20 \mathrm{~min}$. Then, $50 \mu \mathrm{L}$ of TCA $(100 \mathrm{mg} / \mathrm{mL})$ was added and centrifuged at $2000 \times g$ for $10 \mathrm{~min}$. After centrifugation, $100 \mu \mathrm{L}$ of the supernatant was mixed with $20 \mu \mathrm{L}$ of iron(III) chloride $(1 \mathrm{mg} / \mathrm{mL})$ and the mixture was measured at $700 \mathrm{~nm}$. Reducing power was expressed as the 0.5 of absorbance $\left(\mathrm{EC}_{50}\right)$ and $\mathrm{L}$-ascorbic acid was used as a positive control.

\section{ACE inhibitory activity}

The inhibitory activity of ACE was monitored according to the method of Li et al. (2005). A $20 \mu \mathrm{L}$ of sample, $50 \mu \mathrm{L}$ of $5 \mathrm{mM} \mathrm{HHL}$, and $100 \mathrm{mM}$ of sodium borate buffer ( $\mathrm{pH}$ 8.3) containing $300 \mathrm{mM} \mathrm{NaCl}$ were preincubated at $37{ }^{\circ} \mathrm{C}$ for $5 \mathrm{~min}$. The reaction was initiated by the addition of $10 \mu \mathrm{L}$ of ACE solution $(100 \mathrm{mU} / \mathrm{mL})$, and the mixture was incubated at $37{ }^{\circ} \mathrm{C}$ for $30 \mathrm{~min}$. The reaction was stopped by adding $100 \mu \mathrm{L}$ of $1 \mathrm{M} \mathrm{HCl}$, and then sodium borate buffer $(320 \mu \mathrm{L})$, pyridine $(600 \mu \mathrm{L})$, and BSC $(200 \mu \mathrm{L})$ were added to the reaction mixture. After incubation at room temperature for $30 \mathrm{~min}$, the absorbance of reaction mixture was measured at $492 \mathrm{~nm}$ and the captopril was used as a positive control.

\section{Statistical analysis}

The data were analyzed using analysis of variance through the general linear model procedure (SAS Institute, Cary, NC, USA). Duncan's multiple range test was applied to determine the significance of the differences between means $(P<0.05)$.

\section{Results and discussion}

\section{Enzymatic hydrolysis and fractionation}

Recently, the enzymatic hydrolysates have been studied and utilized as nutraceutical resources. In particular, the interest of many researchers on the enzymatic hydrolysates derived from fish and shrimp processing byproducts and the various biological activities such as antioxidant, antibacterial, antiobesity, and antihypertensive activities is growing (Sila et al. 2015; Benoit et al. 2008; Cancre et al. 1999).

In the present study, PBB was hydrolyzed by five specific enzymes including alcalase, papain, trypsin, protamex, and flavourzyme for $8 \mathrm{~h}$, respectively, and $\mathrm{DH}$ values of their hydrolysates were given in Table 2 . The cleavage of peptide bonds by protease leads to decomposition of protein tertiary structure and reduction of the molecular weight of proteins (Adler-Nissen 1986). This reaction also increases in the concentration of free amino and carboxyl groups and its functional properties of proteins (Kristinsson and Rasco 2000). The DH values of $\mathrm{PBB}$ hydrolysates were as follows: protamex $(59.85 \pm 0.09 \%)>$ papain $\quad(58.86 \pm 0.08 \%)>$ trypsin $(58.31 \pm 0.08 \%)>$ alcalase $\quad(55.96 \pm 0.04 \quad \%)>$ flavourzyme (55.68 $\pm 0.08 \%)$. Among the enzymatic hydrolysates, protamex hydrolysate of $\mathrm{PBB}$ showed the highest $\mathrm{DH}$ value.

Table 2 The conditions of enzymatic hydrolysis and degree of hydrolysis of the enzymatic hydrolysates of PBB

\begin{tabular}{lccll}
\hline Enzyme & Crude protein (\%) & $\mathrm{pH}$ & Temperature $\left({ }^{\circ} \mathrm{C}\right)$ & $\mathrm{DH}(\%)$ \\
\hline Alcalase & $70.57 \pm 2.05$ & 8.0 & 50 & $55.96 \pm 0.04^{1, \mathrm{~d}}$ \\
Protamex & $73.92 \pm 0.95$ & 8.0 & 45 & $59.85 \pm 0.09^{\mathrm{a}}$ \\
Flavourzyme & $67.40 \pm 0.16$ & 7.0 & 50 & $55.68 \pm 0.08^{\mathrm{e}}$ \\
Papain & $69.45 \pm 1.33$ & 6.0 & 37 & $58.86 \pm 0.08^{\mathrm{b}}$ \\
Trypsin & $66.62 \pm 0.66$ & 8.0 & 37 & $58.31 \pm 0.08^{\mathrm{c}}$ \\
\hline
\end{tabular}

Enzymatic hydrolysates were obtained from $8 \mathrm{~h}$ under the optical conditions. ${ }^{1}$ Means within the same row with different superscripts are significantly different by Duncan's multiple range test $(P<0.05)$ 
Table 3 Total amino acids composition for the molecular weight cut-off fractions of protamex hydrolysate $(\mathrm{g} / 100 \mathrm{~g})$

\begin{tabular}{llll}
\hline Amino acids & $<3 \mathrm{kDa}$ & $3-10 \mathrm{kDa}$ & $>10 \mathrm{kDa}$ \\
\hline Asp & 3.66 & 4.77 & 3.65 \\
Thr & 1.96 & 2.21 & 1.94 \\
Ser & 1.91 & 2.18 & 1.10 \\
Glu & 6.14 & 7.16 & 6.11 \\
Pro & 2.95 & 0.34 & 3.22 \\
Gly & 5.06 & 4.72 & 5.15 \\
Ala & 4.44 & 4.10 & 4.43 \\
Cys & 0.08 & 0.18 & 0.17 \\
Val & 2.53 & 2.62 & 2.11 \\
Met & 1.44 & 1.24 & 1.74 \\
Ile & 2.21 & 2.54 & 1.88 \\
Leu & 3.80 & 3.68 & 3.73 \\
Tyr & 1.51 & 1.43 & 1.50 \\
Phe & 2.24 & 2.27 & 2.25 \\
His & 1.29 & 1.73 & 1.24 \\
Lys & 3.06 & 3.49 & 3.89 \\
Arg & 2.94 & 3.36 & 3.07 \\
Trp & 0.22 & 0.15 & 0.30 \\
Total & 47.44 & 48.17 & 47.48 \\
\hline
\end{tabular}

\section{Total amino acids contents}

Total amino acid composition of the three MWCO fractions of protamex hydrolysate was presented in Table 3. As shown in Table 3, the total amino acid contents of three MWCO fractions were $47.44 \mathrm{~g} / 100 \mathrm{~g}(<3 \mathrm{kDa})$, $48.17 \mathrm{~g} / 100 \mathrm{~g}(3-10 \mathrm{kDa})$, and $47.48 \mathrm{~g} / 100 \mathrm{~g}$ (>10 kDa), respectively. The total amino acid compositions of three MWCO fractions were similar to each other. All MWCO fractions were rich in Glu, Gly, Asp, Ala, Leu, and Lys, while these fractions contained low levels of Cys and Trp.

\section{Antioxidant activity}

Reactive oxygen species (ROS), containing superoxide $\left(\mathrm{O}_{2}^{-}\right)$, hydrogen peroxide $\left(\mathrm{H}_{2} \mathrm{O}_{2}\right)$, hydroxyl radical $\left(\mathrm{OH}^{-}\right)$, and singlet oxygen $\left(\mathrm{O}_{2}^{*}\right)$, can cause the oxidative damage to the important components such as protein, lipid, nucleic acids and have been associated with the occurrence of various diseases including hypertension (Ngo et al. 2011a, b).

The antioxidant activities of the five PBB enzymatic hydrolysates were measured by the scavenging activity on $\mathrm{ABTS}^{+}$radicals, SOD-like activity, and reducing power (Table 4). The alcalase and protamex hydrolysates of $\mathrm{PBB}$ exhibited noticeable $\mathrm{ABTS}^{+}$radical scavenging activity with $\mathrm{IC}_{50}$ value of $0.16 \pm 0.02$ and $0.17 \pm 0.00 \mathrm{mg} / \mathrm{mL}$, respectively. However, all hydrolysates showed lower $\mathrm{ABTS}^{+}$radical scavenging activity than that of L-ascorbic acid.

SOD, an important antioxidant defense enzyme, catalyzes the dismutation of the superoxide anion $\left(\mathrm{O}_{2}^{-}\right)$into oxygen $\left(\mathrm{O}_{2}\right)$ and hydrogen peroxide $\left(\mathrm{H}_{2} \mathrm{O}_{2}\right)$. The SODlike activity is widely used for assay to measure the inhibition of pyrogallol autoxidation. The results of SODlike activity of the five enzymatic hydrolysates were shown in Table 4. The protamex hydrolysate exerted the greatest SOD-like activity $(2.04 \pm 0.15 \mathrm{mg} / \mathrm{mL})$ among hydrolysates, while the alcalase hydrolysate exhibited moderate activity.

The reducing power is the ability to donate an electron or hydrogen (Dorman et al. 2003). The electron donation capacity of the five PBB enzymatic hydrolysates were evaluated and showed in Table 4. All the $\mathrm{PBB}$ hydrolysates exhibited moderate reducing power.

The antioxidant activities of the three MWCO fractions of protamex hydrolysate were evaluated and showed in Table 5. The $<3 \mathrm{kDa}$ and $3-10 \mathrm{kDa}$ fractions showed potent $\mathrm{ABTS}^{+}$radical scavenging activity $\left(\mathrm{IC}_{50}=0.22 \pm 0.01 \mathrm{mg} / \mathrm{mL}\right.$ and $\left.0.22 \pm 0.00 \mathrm{mg} / \mathrm{mL}\right)$,

Table 4 Antioxidant and ACE inhibitory activities for the enzymatic hydrolysates of PBB

\begin{tabular}{|c|c|c|c|c|}
\hline Sample & $\begin{array}{l}\text { ABTS }^{+} \text {scavenging activity } \\
\mathrm{IC}_{50}(\mathrm{mg} / \mathrm{mL})^{\top}\end{array}$ & $\begin{array}{l}\text { SOD-like activity } \\
\mathrm{IC}_{50}(\mathrm{mg} / \mathrm{mL})\end{array}$ & $\begin{array}{l}\text { Reducing power } \\
\mathrm{EC}_{50}(\mathrm{mg} / \mathrm{mL})^{2}\end{array}$ & $\begin{array}{l}\text { ACE inhibitory activity } \\
\mathrm{IC}_{50}(\mathrm{mg} / \mathrm{mL})\end{array}$ \\
\hline Alcalase & $0.16 \pm 0.02^{3, c}$ & $2.82 \pm 0.72^{\mathrm{a}}$ & $9.42 \pm 0.82^{a}$ & $0.11 \pm 0.01^{\mathrm{b}}$ \\
\hline Protamex & $0.17 \pm 0.00^{b, c}$ & $2.04 \pm 0.15^{\mathrm{a}}$ & $6.75 \pm 0.94^{b}$ & $0.08 \pm 0.00^{c}$ \\
\hline Flavourzyme & $0.20 \pm 0.00^{a, b}$ & $3.13 \pm 0.51^{\mathrm{a}}$ & $4.63 \pm 0.15^{c}$ & $0.11 \pm 0.00^{b}$ \\
\hline Papain & $0.21 \pm 0.03^{\mathrm{a}}$ & $2.59 \pm 0.48^{\mathrm{a}}$ & $4.46 \pm 0.31^{c}$ & $0.11 \pm 0.01^{\mathrm{b}}$ \\
\hline Trypsin & $0.22 \pm 0.02^{\mathrm{a}}$ & $2.44 \pm 0.13^{\mathrm{a}}$ & $6.62 \pm 0.06^{b}$ & $0.13 \pm 0.00^{\mathrm{a}}$ \\
\hline L-Ascorbic acid ${ }^{A}$ & $0.004 \pm 0.000^{d}$ & $0.02 \pm 0.00^{b}$ & $0.04 \pm 0.00^{d}$ & \\
\hline Captopril $^{\mathrm{B}}$ & & & & $0.00002 \pm 0.00000^{d}$ \\
\hline
\end{tabular}

${ }^{1} \mathrm{CC}_{50}$ (50\% inhibitory concentration) values of $\mathrm{ABTS}^{+}$scavenging, SOD-like, and ACE inhibitory activities were expressed as a mean \pm SD

${ }^{2}$ The reducing power was expressed as an $\mathrm{EC}_{50}$ (concentration of the 0.5 absorbance) value

${ }^{3}$ Means within the same row with different superscripts are significantly different by Duncan's multiple range test $(P<0.05)$

${ }^{A} \mathrm{~L}$-ascorbic acid was used as a positive control of $\mathrm{ABTS}^{+}$radical scavenging and SOD-like activities and reducing power

${ }^{B}$ Captopril was used as a positive control of ACE inhibitory activity 
Table 5 Antioxidant and ACE inhibitory activities for the molecular weight cut-off fractions of the protamex hydrolysate

\begin{tabular}{|c|c|c|c|c|}
\hline \multirow[t]{2}{*}{ Sample } & $\mathrm{ABTS}^{+}$scavenging activity & SOD-like activity & Reducing power & ACE inhibitory activity \\
\hline & $\mathrm{I}_{50}(\mathrm{mg} / \mathrm{mL})^{1}$ & $\mathrm{IC}_{50}(\mathrm{mg} / \mathrm{mL})$ & $\mathrm{EC}_{50}(\mathrm{mg} / \mathrm{mL})^{2}$ & $\mathrm{IC}_{50}(\mathrm{mg} / \mathrm{mL})$ \\
\hline$<3 \mathrm{~K}$ & $0.22 \pm 0.01^{3, b}$ & $>10$ & $20.14 \pm 0.39^{a}$ & $0.06 \pm 0.00^{\mathrm{a}}$ \\
\hline $3-10 \mathrm{~K}$ & $0.22 \pm 0.00^{b}$ & $>10$ & $13.84 \pm 0.16^{\mathrm{b}}$ & $0.03 \pm 0.00^{b}$ \\
\hline$>10 \mathrm{~K}$ & $0.24 \pm 0.01^{\mathrm{a}}$ & $>10$ & $7.04 \pm 0.83^{c}$ & $0.03 \pm 0.00^{b}$ \\
\hline L-Ascorbic acid ${ }^{\mathrm{A}}$ & $0.005 \pm 0.000^{c}$ & $0.07 \pm 0.00^{d}$ & $0.04 \pm 0.00^{d}$ & \\
\hline Captopril $^{B}$ & & & & $0.00001 \pm 0.0000^{c}$ \\
\hline
\end{tabular}

Antioxidant and ACE inhibitory activities were measured using the molecular weight cut-off fractions of the protamex hydrolysate

${ }^{1} \mathrm{IC}_{50}$ values of $\mathrm{ABTS}^{+}$scavenging, SOD-like, and ACE inhibitory activities were expressed as a mean $\pm \mathrm{SD}$

${ }^{2}$ The reducing power was expressed as an $\mathrm{EC}_{50}$ value

${ }^{3}$ Means within the same row with different superscripts are significantly different by Duncan's multiple range test $(P<0.05)$

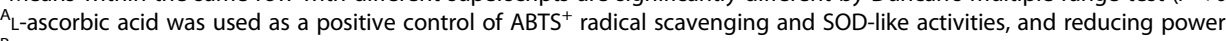

${ }^{B}$ Captopril was used as a positive control of ACE inhibitory activity

while the $>10 \mathrm{kDa}$ fraction was exhibiting stronger reducing power with $\mathrm{EC}_{50}$ value of $7.04 \pm 0.83 \mathrm{mg} / \mathrm{mL}$ than those of the $<3 \mathrm{kDa}$ and $3-10 \mathrm{kDa}$ fractions. However, the three MWCO fractions showed not high antioxidant activities as much as protamex enzymatic hydrolysate.

\section{ACE inhibitory activity}

The inhibition of ACE, a key enzyme regulating the blood pressure, has been recognized as the most effective therapy for the treatment of hypertension. However, many synthetic ACE inhibitors including captopril, enalapril, alacepril, fosinopril, and lisinopril cause side effects such as cough, taste alterations, skin rashes, and angioneurotic edema (Alderman 1996; Cicoira et al. 2001; Vyssoulis et al. 2001). Therefore, it is necessary to develop safe and effective ACE inhibitors from natural products.

The ACE inhibitory activity of the enzymatic hydrolysates of PBB was shown in Table 4. Among the five $\mathrm{PBB}$ hydrolysates, the protamex hydrolysate exhibited the most potent ACE inhibitory activity with $\mathrm{IC}_{50}$ value of $0.08 \pm 0.00 \mathrm{mg} / \mathrm{mL}$, followed by flavourzyme $\quad\left(\mathrm{IC}_{50}=0.11 \pm 0.00 \mathrm{mg} / \mathrm{mL}\right)>$ alcalase $\quad\left(\mathrm{IC}_{50}=\right.$ $0.11 \pm 0.01 \mathrm{mg} / \mathrm{mL})>$ papain $\left(\mathrm{IC}_{50}=0.11 \pm 0.00 \mathrm{mg} / \mathrm{mL}\right)>$ trypsin $\left(\mathrm{IC}_{50}=0.13 \pm 0.00 \mathrm{mg} / \mathrm{mL}\right)$.

The ACE inhibitory activity of the three MWCO fractions of protamex hydrolysate was measured and shown in Table 5. Among the MWCO fractions, the $>3 \mathrm{kDa}$ fraction including $3-10 \mathrm{kDa}$ and $>10 \mathrm{kDa}$ fractions showed significant ACE inhibitory activity with $\mathrm{IC}_{50}$ value of $0.03 \pm 0.00 \mathrm{mg} / \mathrm{mL}$. This result also indicated that high molecular weight fraction, $3-10 \mathrm{kDa}$ and $>10 \mathrm{kDa}$, exhibited potent ACE inhibitory activity compared with protamex enzymatic hydrolysate.

Recently, many researchers have reported that various bioactive peptides derived from fisheries processing by-products including crab shell (Yoon et al. 2013), Pacific cod skin (Ngo et al. 2011a, b), squid skin and muscle (Mendis et al. 2005; Rajapakse et al. 2005), and tuna (Qian et al. 2007; Je et al. 2005; Lee et al. 2010). In the present study, PBB protamex hydrolysate showed notable $\mathrm{ABTS}^{+}$radical scavenging and ACE inhibitory activities. In addition, its MWCO fractions exerted potent ACE inhibitory activities. Therefore, more detailed investigations are necessary to isolate and identify the peptides from active enzymatic hydrolysate and to clarify the mechanism of active peptides.

\section{Conclusions}

In this study, the five enzymatic hydrolysates of PBB derived from fisheries processing by-products were investigated on the antioxidant and ACE inhibitory activities. The PBB Protamex hydrolysate which showed the most potent ACE inhibitory activity than other fractions was fractionated as the below $3 \mathrm{kDa}$, between 3 and $10 \mathrm{kDa}$, and above $10 \mathrm{kDa}$ fractions respectively to isolate the active materials. But these fractions showed lower antioxidant activities than those of enzymatic hydrolysate, while these fractions showed the significant ACE inhibitory activity. In addition, $3-10 \mathrm{kDa}$ and $>10 \mathrm{kDa}$ fractions showed the better ACE inhibitory activity than $<3 \mathrm{kDa}$ fraction. These results suggested that the high molecular weight enzymatic hydrolysate derived from PBB could be used for prevent hypertension.

\section{Acknowledgements \\ This work was supported by a grant from the National Institute of Fisheries Science (NIFS), (R2016064/RP-2016-EC-002). \\ Authors' contributions \\ SB carried out the anti-oxidant and ACE inhibitory activities assay. NY performed the enzymatic hydrolysis and fractionation. KB analyzed the total amino acids composition. CW participated in the design of the study and performed the statistical analysis. All authors read and approved the final manuscript.}

\section{Competing interests}

The authors have no pecuniary or other personal interest, direct or indirect, in any matter that raises or may raise a conflict with our duties. 
Received: 18 July 2016 Accepted: 19 July 2016

Published online: 09 September 2016

\section{References}

Adler-Nissen, J. 1986. Enzymic hydrolysis of food protein. Baking, UK Elsevier $9-56,110-169$

Alderman CP. Adverse effects of the angiotensin-converting enzyme inhibitors. Ann Pharmacother. 1996;30:55-61.

AOAC. 2000. Association of Official Analytical Chemists. 17th Edn., Official Method of Analysis, Washington D.C., USA.

Arvanitoyannis I, Kassaveti A. Fish industry waste: treatments, environmenta impacts, current and potential uses. Int J Food Sci Tech. 2008;43:726-45.

Babu CM, Chakrabarti R, Sambasivarao KRS. Enzymatic isolation of carotenoidprotein complex from shrimp head waste and its use as a source of carotenoids. LWT-Food Sci Tech. 2008:41:227-35.

Bagatini MD, Martins CC, Battisti V, Gasparetto D, da Rosa CS, Spanevello RM, Ahmed M, Schmatz R, Rosa M, Schetinger C, Morsch VM. Oxidative stress versus antioxidant defenses in patients with acute myocardial infarction. Heart Vessels. 2011;26:55-63.

Bauer R. 2004. Remarkable shrimps, adaptations and natural history of the carideans. Animal Natural History Series. University of Oklahoma Press 7, 296.

Benoit C, Rozenn RP, Elisa C, Martine FP. Peptides from fish and crustacean byproducts hydrolysates stimulate cholecystokinin release in STC-1 cells. Food Chem. 2008;111:970-5.

Bhuyana BJ, Mugesh G. Effect of peptide-based captopril analogues on angiotensin converting enzyme activity and peroxynitrite-mediated tyrosine nitration. Org Biomol Chem. 2011;9:5185-92.

Cancre I, Ravallec R, Wormhoudt AV, Stenberg E, Gildberg A, Gal YL. Secretagogues and growth factors in fish and crustacean protein hydrolysates. Mar Biotechnol. 1999;1:489-94.

Chae H, In M, Kim M. Process development for the enzymatic hydrolysis of food protein: effects of pre-treatment and post-treatments on degree of hydrolysis and other product characteristics. Biotechnol Bioproc E. 1998;3:35-9.

Chakrabarti R. Carotenoprotein from tropical brown shrimp shell waste by enzymatic process. Food Biotechnol. 2002:16:81-90.

Cicoira M, Zanolla L, Rossi A, Golia G, Franceschini L, Cabrini G, Bonizzato A, Graziani M, Anker SD, Coats AJS, Zardini P. Failure of aldosterone suppression despite angiotensin-converting enzyme (ACE) inhibitor administration in chronic heart failure is associated with ACE DD genotype. J Am Coll Cardiol. 2001;37:1808-12

Dorman HJD, Peltoketo A, Hiltunen R, Tikkanen MJ. Characterization of the antioxidant properties of de-odorized aqueous extracts from selected Lamiaceae herbs. Food Chem. 2003;83:255-62.

Dr RCP, Lisa JM. Adverse effects of angiotensin converting enzyme (ACE) inhibitors. Drug Saf. 2012;7:14-31.

Guerard F, Dufosse L, Broise D, Binet A. Enzymatic hydrolysis of proteins from yellowfin tuna (Thunnus albacares) wastes using alcalase. J Mol Catal B: Enzym. 2001;11:1051-9.

Hall JE, Coleman TG, Guyton AC. The renin-angiotensin system, normal physiology and changes in older hypertensives. J Am Geriatr Soc. 1989:37:801-13.

Hall JE. Control of blood pressure by the renin-angiotensin-aldosterone system. Clin Cardiol. 1991;14:6-21.

Je YJ, Park PJ, Kim SK. Antioxidant activity of a peptide isolated from Alaska Pollack (Theragra chalcogramma) frame protein hydrolysate. Food Res Int 2005;38:45-50.

Kristinsson HG, Rasco BA. Biochemical and functional properties of Atlantic salmon (Salmo salar) muscle hydrolyzed with various alkaline protease. J Agric Food Chem. 2000;48:657-66.

Lee SH, Qian ZJ, Kim SK. A novel angiotensin I converting enzyme inhibitory peptide from tuna frame protein hydrolysate and its antihypertensive effect in spontaneously hypertensive rats. Food Chem. 2010;118:96-102.

Li GH, Liu H, Shi YH, Le GW. Direct spectrophotemetric measurement of angiotensin I-converting enzyme inhibitory activity for screening bioactive peptides. J Pharm Biomed Anal. 2005;37:219-24.

Marklund S, Marklund G. Involvement of the superoxide anion radical in the auto oxidation of pyrogallol and a convenient assay for superoxide dismutase. Eur J Biochem. 1974;47:469-74.

Mattson MP. Roles of the lipid peroxidation product 4-hydroxynonenal in obesity, the metabolic syndrome, and associated vascular and neurodegenerative disorders. Exp Geront. 2009;44:625-33.
Mendis E, Rajapakse M, Byun HG, Kim SK. Investigation of jumbo squid (Dosidicus gigas) skin gelatin peptides for their in vitro antioxidant effects. Life Sci. 2005; 77:2166-78.

Nielsen PM, Petersen D, Dambmann C. Improved method for determining food protein degree of hydrolysis. J Food Sci. 2001;66:642-6.

Ngo DH, Ryu BM, Vo TS, Himaya SWA, Wijesekara I, Kim SW. Free radical scavenging and angiotensin-I converting enzyme inhibitory peptides from Pacific cod (Gadus macrocephalus) skin gelatin. Int J Biol Macromol. 2011a;49:1110-6.

Ngo DH, Wijesekara I, Vo TS, Ta QV, Kim SW. Marine food-derived functional ingredients as potential antioxidants in the food industry: an overview. Food Res Int. 2011b;44:523-9.

Oyaizu M. Studies on product of browning reaction prepared from glucose amine. Jpn J Nutr. 1986:44:307-15.

Qian ZJ, Je JY, Kim SK. Antihypertensive effect of angiotensin I converting enzyme-inhibitory peptide from hydrolysates of bigeye tuna dark muscle, Thunnus obesus. J Agric Food Chem. 2007;55:8398-403.

Parish RC, Miller LJ. Adverse effects of angiotensin converting enzyme (ACE) inhibitors. Drug Saf. 1992;7:14-31.

Paul M, Poyan Mehr A, Kreutz R. Physiology of local rennin-angiotensin systems. Physiol Rev. 2006;86:747-803.

Rajapakse N, Mendis E, Byun HG, Kim SK. Purification and in vitro antioxidative effects of giant squid muscle peptides on free radical-mediated oxidative systems. J Biochem. 2005;16:562-9.

Ray PD, Huang BW, Tsuji Y. Reactive oxygen species (ROS) homeostasis and redox regulation in cellular signaling. Cell Signal. 2012;24:981-90.

Roberta R, Nicoletta P, Anna P, Ananth P, Min Y, Catherine RE. Antioxidant activity applying an improved ABTS radical cation decolorization assay. Free Radic Biol Med. 1999;26:1231-7.

Sato D, Seino T, Kobayashi T, Murai A, Yugari Y. Determination of the tryptophan content of feed and foodstuffs by ion exchnages liquid chromatography. Agric Biol Chem. 1984;48:2961-9.

Sila A, Kamoun Z, Chlissi Z, Makni M, Moncef N, Sahnoun Z, Nedjar-Arroume N, Bougatef A. Ability of natural astaxanthin from shrimp by-products to attenuate liver oxidative stress in diabetic rats. Pharmacol Rep. 2015;67:310-6.

Takahashi H, Yoshika M, Komiyama Y, Nishimura M. The central mechanism underlying hypertension: a review of the roles of sodium ions, epithelial sodium channels, the rennin-angiotensin-aldosterone system, oxidative stress and endogenous digitalis in the brain. Hypertens Res. 2011;34:1147-60.

Toeroek J. Participation of nitric oxide in different models of experimental hypertension. Physiol Res. 2008;57:813-25.

Vyssoulis GP, Karpanou EA, Papavassiliou MV, Belegrinos DA, Giannakopoulou AE, Toutouzas PK. Side effects of antihypertensive treatment with ACE inhibitors. Am J Hypertens. 2001;14:114-5.

Yoon NY, Shim KB, Lim CW, Kim SB. Antioxidant and angiotensin I converting enzyme inhibitory activities of red snow crab Chionoecetes japonicas shell hydrolysate by enzymatic hydrolysis. Fish Aquat Sci. 2013;16:237-42.

Younes I, Nasri R, Bkhairia I, Jellouli K, Nasri M. New proteases extracted from red scorpion fish (Scorpaena scrofa) viscera: characterization and application as a detergent additive and for shrimp waste deproteinization. Food Bioprod Process. 2015:94:453-62.

\section{Submit your next manuscript to BioMed Central and we will help you at every step:}

- We accept pre-submission inquiries

- Our selector tool helps you to find the most relevant journal

- We provide round the clock customer support

- Convenient online submission

- Thorough peer review

- Inclusion in PubMed and all major indexing services

- Maximum visibility for your research

Submit your manuscript at www.biomedcentral.com/submit 